\title{
Correction to: 3D APT and NOE CEST-MRI of healthy volunteers and patients with non-enhancing glioma at $3 \mathrm{~T}$
}

\author{
Yulun $\mathrm{Wu}^{1,2}$ (1) $\cdot$ Tobias C. Wood $^{3} \cdot$ Fatemeh Arzanforoosh $^{1,2} \cdot$ Juan A. Hernandez-Tamames ${ }^{1} \cdot$ Gareth J. Barker $^{3}$. \\ Marion Smits ${ }^{1,2}$. Esther A. H. Warnert ${ }^{1,2}$
}

Published online: 5 February 2022

(c) The Author(s) 2022

\section{Correction to: \\ Magnetic Resonance Materials in Physics, Biology and Medicine \\ https://doi.org/10.1007/s10334-021-00996-z}

The original version of this article unfortunately contained a mistake. The following author names were incorrectly structured.

Tobias C. Wood

Gareth J. Barker

Juan A. Hernandez-Tamames

Esther A. H. Warnert

The original article has been corrected.

Open Access This article is licensed under a Creative Commons Attribution 4.0 International License, which permits use, sharing, adaptation, distribution and reproduction in any medium or format, as long as you give appropriate credit to the original author(s) and the source, provide a link to the Creative Commons licence, and indicate if changes were made. The images or other third party material in this article are included in the article's Creative Commons licence, unless indicated otherwise in a credit line to the material. If material is not included in

The original article can be found online at https://doi.org/10.1007/ s10334-021-00996-z.

Yulun Wu

y.wu@erasmusmc.nl

$\triangle$ Esther A. H. Warnert

e.warnert@erasmusmc.nl

1 Department of Radiology and Nuclear Medicine, Erasmus MC, Dr. Molewaterplein 40, 3015 GD Rotterdam, The Netherlands

2 Brain Tumor Centre, Erasmus MC Cancer Institute, Rotterdam, The Netherlands

3 Centre for Neuroimaging Science, King's College London, London, UK the article's Creative Commons licence and your intended use is not permitted by statutory regulation or exceeds the permitted use, you will need to obtain permission directly from the copyright holder. To view a copy of this licence, visit http://creativecommons.org/licenses/by/4.0/.

Publisher's Note Springer Nature remains neutral with regard to jurisdictional claims in published maps and institutional affiliations. 